\title{
VOJTECH BOHÁČ
}

\section{CURRICULUM VITAE OF D. MIKULÁŠ (NICOLAS) RUSSNÁK THEOLOGIAN AND LITURGIST}

University professor D. Mikulás Russnák came from a clerical family. His father, Pavol Russnák was a Catholic priest of the Byzantine rite. His mother Jolany, originally ramed Brinszky, came from Varhañovee, and was a daughter of a priest.

Mikulás Russnák was born on 30 April 1878 in Sopkovce. He received the sacrament of baptism and confirmation in Sopkovce on 7 May 1878. He had three siblings. His younger brother Pavol was a priest and doctor of sacred theology. He was a vice-dean at the seminary in Presov, and a canon and a parish priest in Závadka. He died on 18 March 1943. Of his two sisters, Gizela was older and Etelka was younger than Mikulás. Gizela married Viktor Leukanic, a Catholic priest of the Byzantine rite in Klecenov. Etelka married Július Szinyei-Merse, a lawyer. The children were brought up in the Catholic faith, as would be obvious for the family of the Catholic priest.

The family atmosphere of devotion and catholicity remained an everlasting value for Mikulás. His mother Jolana died on 7 June 1898 and his father Pavol died on 27 June 1921.

\section{STUDIES AT ELEMENTARY AND HIGH SCHOOL}

In 1881 Mikulás Russnák was sent from Sopkovce to Durđơ̌. Although Mikulás Russnák was born in Sopkovce in Humenné County, during the years 1884/85 he attended the first year at the elementary school in Durd'os. He was then six years old. He also attended the second grade at the Greek Catholic school in Durd’os.

From 1886/87 he continued his studies as a third grade student at the elementary school in Presov, finishing with excellent results. He attended the fourth grade in Presov in 1887/88. The final and summary evaluation in the transcript was: good. 
The year 1886 became very important in Mikulás's memories because of his first communion in Durd'os. He received Holy Communion from the hand of his father - a priest.

After he had finished the elementary school in Prešov he continued his studies at a grammar school. During that time there was a Royal Grammar School of eight grades. Mikuláx Russnák began his first year at the grammar school on August $30^{\text {th }} 1888$. He finished the first grade with very good results.

From the very beginning of his studies at the grammar school he had distinguished himself in languages. He studied Latin for eight years and Greek for four . He was taught the German language from the third grade. The official Hungarian language caused him no problems. He also learnt Ruthenian for the whole eight years. Despite his less enthusiastic approach to scientific subjects, he successfully passed them, too.

His best results were in religious education, which was evaluated first in all the transcripts at both the elementary and the high school. We cannot disregard a report in the transcripts which commented on the behaviour of students during the liturgy. Here it was always written that the behaviour of student Mikulás Russnák had been proper, devoted, and eager (from the third grade through to the eighth grade). According to the decision made by the head of the high school on 13 February 1889 No 5392, he was freed of school tuition during his studies. He did not take any stipend. A vocation to the priesthood had been formed in the soul of the young student during the time of his studies. He was used to praying and to making resolutions to fast. During his high school studies he stayed mainly on campus, but for a period of time also lived out at in private quarters.

\section{THE SCHOOL LEAVING EXAMINATION}

Mikulás Russnák studied at the Royal School during the years 1888-1896. He completed his studies with a leaving examination on 13 June 1896. The examination consisted of seven subjects. He received an excellent evaluation in five subjects: Hungarian language and literature, Greek language and literature, history, mathematics, and physics. In two subjects - German and Latin languages - he achieved a 'well done' evaluation. Although religious education, geography, philosophy, biology and descriptive geometry were not examined, their grades helped to complete the whole profile of the student. The committee of seven members heard that Mikulás Russnák had succeeded in the exam, and they certified him able to continue his studies at university.

\section{THEOLOGICAL STUDIES AND PRIEST ORDINATION}

After the leaving examination he applied for the espiscopal seminary in Prešov. Bishop D. Ján Vályi accepted his application in July 1896 . He sent him to 
study at the Theological faculty of the Royal University in Budapest. The spiritual formation of the future priest took place in the main seminary in Budapest.

On 2 October 1896 Mikulás was accepted as a corporate student at the Theological faculty by the provost and the dean of the faculty. This was confirmed by their signatures in the index of the college students.

During his studies, according to his entry in the index he took theological disciplines, including fundamental theology, Biblical archeology, Church history, Biblical studies of the Old Testament and the New Testament, canon law, moral theology, philosophy, pedagogy, pastoral theology, and Christian art. In particular he studied the Hebrew language - four hours a week during his first semester - and Hebrew exegesis in his third semester (again four hours a week). The Syrian and Chalcedonian languages were taught three hours a week during two semesters. Likewise Arabic was taught three hours weekly during two semesters.

In his second year of studies his mother passed away on June $7^{\text {th }} 1898$. He attended the funeral.

All of his examinations were passed on time. Out of 26 exams recorded in the index only four had not been evaluated as excellent. He graduated from the university in Budapest on 11 June 1900. Because he was too young for the priesthood he had to wait for a dispensation. Having received it, he was consecrated by the bishop of Prešov in the following sequence :

On August $19^{\text {th }} 1900$ he received "postriženije" (a special act of cutting the hair while receiving the consecration as a deacon) a deacon.

On August $21^{\text {st }} 1900$ he received the sub deaconry and on August $23^{\text {rd }}$ became

On August $26^{\text {th }} 1900$ he was ordained priest as an unmarried man.

He celebrated the first holy liturgy on September $2^{\text {nd }}$ in his father's parish in Durdos. The next day he offered mass for his mother who had passed away and could not see his consecration. Afterwards in his decree bishop D. Ján Vályin confirmed all the consecrations, and in the second decree he also confirmed his jurisdiction.

\section{ACADEMIC DEGREES}

Mikulás Russnák was sent to the University of Budapest with the goal of achieving the doctor's degree in sacred theology. He was an excellent student and the goal was realistic. In accordance with the university's educational and study programme he passed the following specified rigorous examinations:

The first rigorous exam taken on 18 March 1899 in biblical science and eastem languages, after which he became a bachelor of theology.

The second rigorous exam taken on 3 February 1900 in fundamental theology and special dogmatic theology, after which he gained a licentiate degree in the sacred theology. 
The third rigorous exam taken on 30 October 1900 in moral and pastoral theology, after which he gained a master degree in the sacred theology.

The fourth rigorous exam taken on 17 April 1901 in canon law and Church history

After his outstanding achievement in the specified exams he was successfully awarded the title of doctor of sacred theology.

No-one would have achieved a doctor's degree in such a short period of time before.

On 20 January 1902 bishop Vályi appointed Mikulás Russnák to give lectures in Biblical science at the Theological Academy. In a written decree of 17 March 1912 the same bishop appointed him as a professor of moral and pastoral theology. Mikulás taught these disciplines for a short period of time.

In the decree of 14 August 1902 he was appointed by bishop Vályi to a permanent lectureship in dogmatic theology. By the same decree he was appointed headmaster of St. John the Baptist Grammar School. He taught dogmatic theology until 1950 when the Greek Catholic Church was eliminated by totalitarian forces.

On 10 October 1903, owing to the sickness of doctor Jozef Vojtoviz, he was appointed to substitute for him in teaching canon law. At the same time he substituted for him as provost of the St. John the Baptist Institute. He held this post for three semesters. Because of continuing sickness he remained in the post longer.

To complete his pedagogical role it must be said that he was also appointed a catechist of Greek Catholic students at Sancta Maria Institute.

Regardless of all the duties given him by his bishop, he did not neglect academic and research activities. He focused on the primacy of the pope, purgatory, the epiclesis, the Holy Spirit proceeding from the Father and the Son, and priestly ordination in the Byzantine rite, as well as the deficiency of the Byzantine legal order. His articles were published in various religious and secular periodicals in Prešov, Lvov, Budapest, and subsequently published in a book form. This was the 'EGYHÁZJOG' (the Church's law) published in Presov in 1915.

Thanks to his academic work he was recognized by the academic committee of the Theological Faculty in Budapest, where he had previously studied . In assembly the academic committee resolved to honour Doctor Mikulás Russnák with the title "Doctor Collegiatus" for his academic and literary activities.

In 1917 he became a member of the literary association of Cardinal Peter Pazmányi in Budapest. In 1936 he received a similar honour from - and was granted membership of- the theological and literary association in L'vov.

From 1902 to 1936 he taught dogmatic theology at the Theological Faculty in Prešov. In 1936 the minister of education in Prague appointed him to become a professor in the new Theological Faculty in Bratislava.

To take the position he had to accept a canonical mission. With a "Nihil obstat" from the Holy See, he obtained his canonical mission from bishop Dr. Pavol Jantausch, at that time apostolic administrator in Trnava. Mikulás Russnák acceded 
to the office of a professor in Bratislava in October 1936. During the academic year 1946-47 he was in charge of the faculty as its highest academic dignitary - dean. There he worked as a professor until 1 October 1948.

\section{THE CHURCH'S OFFICES AND DEGREES}

After bishop J. Vályi had agreed in his decree of 4 September 1900 to ordain Mikulás Russnák, he was sent as a chaplain to the parish of Sósujfalu (Ruská Nová Ves) where vdp. Michal Lipcsey was a superior. He stayed there for thirteen months. During his stay in Sósujfalu he passed two rigorous examinations and gained a doctor's degree in theology.

The bishop of Prešov in his decree of 31 October 1901 appointed him to become a chaplain in the parish Sajópetri, where vdp. Alojz Gaganetz was his superior.

From 20 January 1902 to the end of the year 1903 he was a vice-rector of the seminary and from 17 March 1902 to the end of the year 1903 he was a spiritual director of clerics.

On 8 October 1903 he was appointed as a "defensor vinculi" in a court of the first degree. On 21 July 1924 he was nominated for the position of chairman of the court - vicarious, iudicales, praeses. He held this office until 1940, when he gave it up.

On 9 December 1906 he received a decree appointing him as an assessor a counsellor. In 1910 he was appointed as a school inspector in the diocese.

On 15 January 1915 he was promoted to the post of "canon magister", and on 10 April 1916 he was promoted to the post of "canon scholastic". In 1918 he was appointed to the post of vicar-general. In February 1926 he took the post of "canon cantor", and on 17 July 1928 he became a "canon lector". On 22 December 1928 he was promoted to the post of prelate of the Holy Father Pius IX.

\section{VICAR-GENERAL}

Of the above-mentioned degrees the highest office he gained was the office of vicar-general. He was appointed to this office by bishop Stefan Novák on 1 October 1918, during the establishment of the first Czechoslovak Republic. Afterwards bishop Novak left the diocese of Prešov, and he moved to Budapest.

Mikulás Russnák became a vicar-general during great social and political changes. It was a difficult and challenging time. His work could be characterized and summed up in the following points :

1. He took care of the spiritual needs of believers and priests. He organized missions for believers in parishes, and spiritual exercises for priests.

2. Financially and materially he supported canons and professors and dealt with anxieties regarding the material care of priests (with help from the USA, and from the apostolic administrator Gabriel Martak, the former priest of Presov diocese). 
3. He maintained a critical and decisive resolve to preserve Church order according to her canons and principles in matters of priests' transfers and permissions to leave for the USA (nobody left under unjust terms but was properly sent out).

4. He resolved the problem concerning the new Gregorian calendar, which he implemented on 24 June 1916. He also used religious sanctions against priests or believers who did not obey.

5. He prevented incompetent people from getting involved in the Church's affairs. In this he had the full support of the apostolic nuncio in Prague, J. E. Marmaggi and A. F. Colbrie - a bishop of Kosice diocese.

6. He started a great campaign to preserve Catholic schools under the Church's government and administration. At the end none was handed over to civil school control.

7. He eliminated the offences of those separated from the Church - emigrants from Russia who had fled before the Revolution. He sent priests and members of religious orders to endangered places.

8. He welcomed a Redemptorist order of monks and a Basilian order of nuns in the diocese.

9. He successfully made and accumulated financial savings, despite difficult political and social circumstances.

He held the position of vicar-general for almost nine years. His holding of the office had two phases:

a) From 1918 to 28 October 1922 , when he governed the diocese by himself.

b) From 28 October 1922 to 20 February 1927 when he became vicar-general of a new appointed apostolic administrator in Prešv - the Greek Catholic bishop D. Dionýz Nyáradyi.

\section{A PROVOST AND A PROTONOTARY APOSTOLIC}

After bishop J. E. Pavol Peter Gojdic took up office in the diocese (20 February 1927) Mikuláš Russnák began to focus on academic activities, work at the Chapter, and involvement in the religious court. After he became a professor at Bratislava university he began to travel there every week. He continued both his academic work and his work for the Presov diocesan centre. Noteworthy was his election to the office of provost at the Presov Chapter on 25 October 1947. He was inaugurated to the office by bishop Pavol Peter Gojdix on 7 December 1947, and on 15 December 1947 the same bishop honoured him with the privilege of wearing a mitre.

At the request of bishop Gojdic, Pope Pius XII appointed him to the office of protonotary apostolic. The apostolic nuncio announced this to the bishop of Presov on 4 June 1948. According to the rules, Mikulás said the confession of faith in the presence of auxiliary bishop Vasil Hopko. who had been deputed for this purpose 
by Archbishop Alfonz Carinci - dean of the Apostolic Protonotaries. The same archbishop sent a confirmation and accepted the confession of faith of the new dignitary.

This honour has not yet been recognized, nor it has been mentioned due to the unfortunate years that the Catholic Eparchy of the Byzantine rite in Prešov and its members have gone through.

\section{HIS DESTINY AFTER THE LIQUIDATION OF THE GREEK CATHOLIC CHURCH}

A terrible and grievous day - 28 April 1950 - witnessed the liquidation of the visible structures of the diocese of Prešov by the violent authorities of the communist republic. The living part of the Catholic Church of the Byzantine rite ceased to exist. Bishops, priests, friars, nuns and believers were captured and deported to concentration camps. Many of them were imprisoned.

Professor M. Russnák had his own house in Prešov. From 28 April 1950 the house was controlled by the secret police, though they did not legitimate persons coming to or leaving the house. Even if M. Russnák had been allowed to leave his house, he had nowhere to go since the cathedral was taken over by the Orthodox Church, and he could not celebrate the liturgy. He was kept inside the house from 28 April until 18 May 1950 when at 10 p.m. the police came and took Mikulás Russnák. When the police asked him to go with them he calmly said: "Wait, I will put on clothes and I'll go with you." He packed some things and went with the police. He was sent to the central camp in Podolinec - at the Redemptorist monastery. Later he was sent to the prison in Hlohovec where he celebrated the fiftieth anniversary of his ordination as a priest. Later he was sent to Bác. His relatives wanted to take him home from Báč, but the state office refused their request.

\section{HIS DEATH AND A FUNERAL}

On 26 November 1954 early in the morning before the holy liturgy he did not feel well and collapsed. He was taken to the hospital in Bratislava where it was realized he had had a stroke on the right side. He died in the hospital on 2 December 1954 .

The funeral took place in Bratislava in Martin's cemetery on 4 December 1954. Many believers and priests participated. He was buried by Leopold Adamcík, vicar-general of Trnava. Since he was buried in Bratislava, and crowds were not allowed in the east of Slovakia, the burial was conducted without any interruption of national security forces.

Mikulax Russnák awaits the second coming of Christ and the resurrection of his body on Martin's cemetery in Bratislava. 


\section{THE WORK OF MIKULÁS̆ RUSSNÁK}

When we look at the academic work of Mikulás Russnák from the very beginning we are convinced of his hard work, patience, zeal, and eagerness for academic and literary activity. His legacy to us is 191 academic titles. Only a minor part was printed and published during his lifetime: the majority remains in manuscript in his library.

Some of his writings were taken to the library of Matica Slovenská in Martin. The rest of his books were taken to other libraries.

Some personal work of the author was saved by his relative Dr. Pavol Russnák - a priest - who took it and held it in Bratislava raca at no.108 Alstrova street. Nowadays his work has been moved to the East - West Centre of the University of Trnava in Košice city.

\section{COLLECTION OF HIS WORK}

He began to write early as a seminarian, writing for various periodicals published in Budapest: The dissertation written in 1901 was his first theological writing. The theme was dogmatic, as expressed in its title: De processione Spiritu Sancti a Filioque. The book was published in Prešov.

In 1902, during his second appointment as a chaplain in Sajópetri, he wrote his second work with the title Sacramentum Poenotentiae. The third publication of the young priest and theologian was historical. Its title "Az Alumneum torténete" speaks of the history of "Alumneum" in Prešv. It was published in 1907.

He continued his work even during his post in Prešv. He wrote for various religious as well as public journals. The religious journals included Religio, Egyházi kőzlőny, Görőgkatolikus szemle, and Duspasztyr (Užhorod), and the public ones Alkotmány, Felvídek, Sáros, and Kassai hírlap. Although his first writings were books during this first period of literary activity hewrote mostly articles and essays in the above mentioned magazines.

From 1908 to 1913 in total he wrote 61 articles. In 1916 he published five more. Then the intensity of his response to theological and social problems in magazines diminished.

In the years 1917, 1932, 1933, 1940, 1941, 1942, 1943 only one article occurred at a time, with the exception of the year 1926 when he wrote two articles in the Duspastyr magazine in Užhorod.

The themes of the articles related to actual problems of the time: social issues, emigration, industry, youth, schools, pensions of priests, the problem of the calendar, and other theological discussions.

The articles of Mikulás Russnák can be classified according to content as dogmatic, moral, legal, liturgical and social (articles that foresee the social teaching of the Church). 


\section{A LIST OF HIS WRITINGS}

M. Russnák wrote his academic work in three languages. He wrote 143 works in the Latin language, 36 in Hungarian, and 9 in the Ruthenian language. He was a redactor of the "Felvidék" magazine, which was published in Prešv. He published 18 articles in this magazine. His literary and academic work began in 1901 and lasted until 1949.

Books

1. Autobiography - Fragopoli / 1943

2. Biography in imanigibus - Fragopoli / 1947

3. De libertate et independentia Ecclesiae Cath. / 1942

4. Adatok nagy emberekrỏl I. /1948

5. Adatok nagy emberekröl II. / 1948

6. Adatok nagy emberekröl III. / 1948

7. Disciplina genuflectendi iuxta ritum Orientalem / 1938

8. Regarding the Holy Spirit proceeding from the Son / Dissertation / 1901

9. Simonia / 1942

10. De modo agenda nostrorum in litando Sacrum / 1942

11. Our situation I. / 1948

12. Our situation II. / 1948

13. Our situation III. /1949

14. Our situation IV. / 1949

15. Orthodox - catholic dogmatics / 1930

16. Dohmatics - catholic doctrine / 1909

17. Purgatorium et Ecclesia Orientalis / 1937

18. Purgatory and the Byzantine Church / 1913

19. Sacramentum Poenitentiae $/ 1913$

20. Epiklézis / 1926

21. Liturgy of the Byzanzine Church

22. De indulgentiis / 1944

23. De processione Spiritus Sancti a Filioque / 1938

24. De Deo Uno, Bratislava / 1941

25. De Deo Triuno, seu de Spiritu sancti trinitate / 1941

26. De Creatore I. /1942

27. De Creatore II. / 1942

28. De Deo Redemptore I. /1943

29. De Deo Redemptore II. / 1943

30. De Deo Redemptore II. / 1943

31. De Deo Redemptore III. Christologia / 1943

32. De Christologia IV. Soterológia / 1943

33. Mariologia I. / 1936 
34. Mariologia II. / Citata ex R. Or. M. in ritu Or. / 1937

35. Mariologia III. / Cultus apud Or. / 1938

36. Prelectiones Dogmaticae - De gratia Divina / 1941

37. De Deo sanctificatore / 1942

38. Homilies on the Holy Eucharist I (a handwriting) / 1943

39. Homilies on the Holy Eucharist II. (a handwriting) / 1943

40. Homilies on the Holy Eucharist III. (a handwriting) / 1944

41. De Deo Terminatore / 1941

42. treatises and interpretation / 1932

43. A proper celebration of the liturgy I. / 1948

44. A proper celebration of the liturgy II. / 1948

45. Lingua Staroslavica I. / 1941

46. Lingua Staroslavica II. / 1941

47. A book critique I. / 1947

48. Adnotationes historicae de " 20 "/ 1947

49. A book critique II. / 1947

50. Editio Crypto - Ferratensis Lit. 1940 - 41 Lit. UV / 1942

51. Editio Crypto - Ferratensis Lit.1942 Lit. UV / 1942

52. Editiones librorum SSA ex 1942 Liturgikon ,Servant , / 1944

53. a) Primatus Rom. Pontificis I. / 1927; b) Primatus Rom. Pontificis II. / 1927

54. Tractatus varii I. / 1931

55. Tractatus varii II. / 1933

56. Tractatus varii III. / no year given

57. Tractatus varii IV. $/ 1936$

58. Tractatus varii V./ 1938

59. Tractatus varii VI. Disciplina barbas alendi / 1940

60. Tractatus varii VII. / 1942

61. Tractatus varii VIII. / 1943

62. Tractatus varii IX. / 1943

63. Tractatus varii X./1944

64. Tractatus varii XI. / 1944

65. Tractatus varii XII. / 1946

66. Tractatus varii XIII. / 1947

67. Tractatus varii XIV. / 1947

68. Tractatus varii XV./1945

69. Tractatus varii XVI. / 1947

70. Tractatus varii XVII. / 1948

71. Tractatus varii XVIII. / 1948

72. Tractatus varii XIX. / 1949

73. Festum Regis Christi I. / 1935

74. Festum Regis Christi II. / 1935

75. Breviarum Orientalium / 1933 
76. Citata. Ordine alphabetorum ex. Fontibus literarum

77. Eternal truth / 1936

78. Russian words in Hungarian language / 1932

79. Psalterium cum alphat. ord. stichorum / 1932

80. Ordinationes meae tamquam Vic. Gen. / 1931

81. Disciplina ieiunande E. C. ritum Or. / 1929

82. Fragopolis . Tit. Dioec. Fragopolitanae / 1942

83. Facetiae / 1948

84. Lyra latina moderna / 1943

85. C J C respecte habito edendi Cod. Pro iure E C Or / 1929

86. CBJC I. Pii papae XI. Auctoritate promulgatus

87. CBJC II. / no year given

88. CBJC III. / no year given

89. CBJC IV. / no year given

90. CBJC V. / no year given

91. CBJC VI. / no year given

92. CBJC VII. / no year given

93. A new codex and law order in the Byzantine Church / 1918

94. CBJC IX. Pii XI. Auctor. Promulgatus

95. CBJC X. Historia Cod. Articuli var. auct.

96. CBJC XI. Cann. 144- 725/1933

97. CBJC XII. Cann. 726-1153/1934

98. CBJC XIII. Cann. 1154-1551/ 1936

99. CBJC XIV. Cann. $1552-2194 / 1936$

100. CBJC XV. Cann. 2195 - 2414 / 1936

101. CBJC Ius Matrimoniale / 1949

102. Martyrologium Orientale I. 118 / 1944

103. Martyrologium Orientale II. Recensio Sanctorum 106 / 1944

104. Martyrologium Orientale 119 / 1945

105. Martyrologium Orientale 103 / 1944

106. Martyrologium Orientale $120 / 1945$

107. Martyrologium Orientale $109 / 1944$

108. Martyrologium Orientale $109 / 1944$

109. Martyrologium Orientale 113 / 1944

110. Sancti mensium I. II. $121 / 1945$

111. Sancti mensium V. VI. VII. VIII. 114 / 1944

112. Sancti mensium II. III. IV. 110/1944

113. Sancti mensium V. VI. VII. VIII. 112/ 1944

114. Sancti mensium III. IV. 122/1945

115. Sancti mensium V. VI. $123 / 1945$

116. Sancti mensium VII. VIII. 124 / 1945

117. Sancti mensium vide $102 / 1946$ 
118. Sancti mensium vide 104 IX. X. / 1946

119. Sancti mensium vide 107 XI. XII. / 1946

120. Sancti mensium vide 111 I. II. / 1946

121. Sancti mensium vide 115 III. IV./ 1946

122. Sancti mensium vide 116 V. VI. / 1946

123. Sancti mensium vide 117 VII. VIII. / 1946

124. Index Santorum Martyr. Or. Plenus / 1944

125. Data Martyr. Rom. Aleberrina / 1944

126. Index / 1946

127. Data specialia utriusque Martyr / 1947

128. Homilies for the Lent season and Palm Sunday / 1914

129. Funeral homilies / 1914

130. Feast homilies / 1914

131. Sunday homilies / 1913

132. Lent homilies / 1913

133. Marian and occasional homilies / 1913

134. The Church's Law I. / 1915

135. The Church's Law II. / 1915

136. The Church's Law III. / 1915

137. Exercitia sacra / 1933

138. A prayer book / 1913

139. Our American circumstances I. / 1932

140. History of Alumneum. Marks of a doctoral degree / 1907

141. Our abroad I. / 1913

142. Our abroad II. / 1932

143. The rite / 1910

144. The Gospel and apostolate / missing

145. Libery S. Script. sub respectu lectionum variantum / 1940

146. Argumenta veritatis revelatae, hausta ex test. Lit. I. / 1939

147. Argumenta veritatis E. liturgica II. / 1939

148. Argumenta veritatis E. liturgica III. / 1939

149. Lectiones variants Vulg. LXX et Staroslav. Genesis et Exodus / 1939

150. Lectiones II. Lev. Num, Deut. /1939

151. Lectiones III. Josue , Judicum Ruth/ 1939

152. Lectiones IV. Lib. I Samuelis, quem Vulg. Primum Reg. vocat, Lib 2Sam quem Vulg. II. Regum vocot, Lib regumsecundum Hebraeos, Primus Malachim, Lib Regum secundum Hebraeossecundum Malachim / 1939

153. Lectiones V. Paralipomenon, I. II. Esdrae, Tobiae, Judith, Esther , Job /1940

154. Lectiones VI. Psalmorum , Proverbiorum / 1940

155. Lectiones VII. Eccl.Canticum . Eccu. / 1940

156. Lectiones VIII. Propf. Is. Jer. / 1940

157. Lectiones IX. Threni , Ep. Jeremiae, Baruch, Ezech, Dan. / 1940 
158. Lectiones X. Osee ... Twelve small prophets / 1940

159. Lectiones XI. Machabeorum I. II. Esdrae III. IV. / 1940

160. Lectiones XII. Nov. Test. Evangelia I-IV Act. Ap. Epistolae s. Pauli I- XIV. Ep. Cath I - VII Apocalypsis / 1940

161. Essays I./ 1944

162. Essays II. / 1944

163. Essays III. / 1944

164. Quotations from the Old Testament / 1935

165. Quotations from the New Testament / 1936

166. S. Theol. Dogm. In forma Sermonum. I. De Deo uno / 1934

167. S. Theol. De Doe Triuno / $1934-35$

168. S. Theol. De Deo Creatore I. / 1936

169. S. Theol. De Deo creatore II. / 1937

170. S. Theol. De Deo Redemptore / 1938

171. S. Theol. De B. Virgine Maria / 1939

172. S. Theol. De Gratia Divina I. / 1938

173. S. Theol. De Gratia Divina II. / 1939

174. De Deo Sanctificatore I. / 1938

175. De SS Eucharistia II. / 1935

176. De Sacramentalibus / 1939

177. De sanctificatione hominum / 1939

178. De S. Communione / 1940

179. De Cultus SS Euch. Apud Orientales 1934

180. De libris liturgicis respectu habito Commis Leopol. II. / 1935

181. De releus eschatologicis / 1933

182. The agreement of the calendar / 1918

183. Mariologia / 1943

184. De primatu Romani Pontificis I. / missing

185. De primatu Romani Pontificis II. / missing

186. De primatu Romani Pontificis III. / missing

187. Upper land - a newspaper / 1910

188. Upper land - a newspaper / 1911

189. Index summaries / 1949

190. Our situation XXII: / 1949

The above mentioned writings are mostly in manuscript. The following works were published:

1. De processione SS a Filioque, fragopoli, 1901

2. History of Alumneum, Eperjes, 1907

3. Discipline in fasting in the Byzantine Church, Budapest, 1909

4. Homilies, Eperjes, 1909

5. Catholic doctrine, Eperjes, 1909 
6. the Purgatory and the Byzantine Church, eperjes, 1914

7. A Liturgy of the Byzantine Church, Budapest, 1915

8. A prayer book, Prjašev, 1916

9. Pensions of Prešov's See, Eperjes, 1918

10. New codex of the canon and law order of the Byzantine Church. Prešov, $2+28$

11. Marks of a doctoral degree, Eperjes, 1919

12. Epiclesis, Eperjes, 1926

13. De assumptione BMV corpos corporali, 1932

14. De Immaculata Conceptione BMV, 1936

15. Lingua Staroslavica, Prešov, 1943

16. Disciplin ieiunandi Ecclesiae catholicae secundum ritum orientalem, Fragopoli, 1929

17. CIC respectu habito edendi pro iure Ecclesiae Catholi cae Orientali Codicem iuris canonici, Pragae, 1931

18. De immaculata Conceptione B. Virginis Mariae, Prjašev, 1933

19. Lingua Staroslavica, Fragopoli, 1943

20. Breviarium Ecclesiae Orientalis

TITLES DIVIDED ACCORDING TO THE DISCIPLINES

We can divide the extensive work of Mikulaśs Russnák into the several branches:

- Dogmatic writings (20)

- Writings on moral theology (7)

- Canon law (11)

- Biblical writings (15)

- Homilies and pastoral writings (22)

- Historical writings (3)

- Ascetic writings (2)

- Linguistic writings (4)

- Other writings (40)

- Liturgical writings (38)

The value of Mikulás Russnák's work was also recognized by the Apostolic See, to which Mikulás individually had introduced some of his books: Egyházjog; Proiectum incl. Comissionibus de canonibus inde 144-214 (15 volumes); Festum Regis Christi (2 volumes); broadcast on Editio Crypto-Ferratensis ä 2 volumes); Disciplina ieiunandi Ecclesiae catholicae secundum ritum orientalem. The Holy See really appreciated and recognized his above mentioned works.

His writing on the Assumption of the Blessed Virgin Mary was very important in relation to the declaration of the feast. The Holy See in its letter of thanks to 
the ordinate of Prešov praised the writing as the best out of thousands, and recognized only one author: Th Dr. Mikulás Russnák, a priest of the Prešov's Eparchy

Through this honour bestowed by the Holy See the above mentioned work won a celebrated name for the Eparchy and for Mikulás Russnák throughout the whole Catholic world.

All the characteristic features are more valid since the author intentionally created and interpreted them as means towards the salvation of immortal souls. 